In the last issue of this bulletin the nesting season of the Horned Lark was questioned by Mir. Gilroy. On April 26, 1946, when the ground was still partly covered with snow, I found a nest containing four eggs.

(This gives us the earliest date on our records; now who can give us one later than we have? Ed.)

Starlings seemed to have recently invaded this territory, for as far as I know none had been reported here unti.l. I saw five on August 28. There were many blackbirds around at that time but the shorter tails and manner of flight of the others suggested starlings. On october 2, I saw a flock of 22 west of the city. Since then I have seen many more, in flocks ranging from 4 to 200 .

Has anyone observed a decrease in the Chipping sparrow population of his area? Last year not a single bird of this species was seen at Sandwith. This year, in North Battlefora, I saw approximately a dozen, one of which unfortunately lost its life after flying into telephone wires.

While wandering near the Saskatchewan River on October 2, a black hawk flew over me. Its size, shape, voice and manner of flight suggested that it was a melano Marsh Hawk. As I stood twenty feet below it, the colouring resembled that of a Turkey Vulture, that is, generally black all over, except for grey. primary and secondary wing feathers. Is there any possibility for my mistaking this bird for another species?

\title{
NATURE STUDY IN THE SCHOOL
}

One of the most interesting nature observation lists that has come to our notice is that prepared by the pupils of Ionsdale School, under the airection of their tea her, Mrs. Margaret A. Anderson, of Loon Lake. The list was submitted to the Provincial Museum.

It is not a short one, but made up of 323 separate observations by the boys and girls, made practically every day from March 31 to June 25. The fact that items were so varied indicates that the interest of the pupils had been aroused in every phase of nature.

It contains dated entries such as Pussy Willows, Groundhog, frogs! croaking, Dragonfly, Phoebo, Arctic Tern, Brown Bear, Cranes, frog's eggs, mating of Blue Jays, Wild Foxglove, brown rabbits, Chokewerries in bud, Buffalo Bean blossoms, Monarch Butterfly, Garter Snake, Morals, young Magpie, Dandelion seeds, Mallard ducklings, Wren's nest, Baby Robins, Fireflies, 'Bats, Cowbird eggs, Dewberry blossoms, Mudhen's nest, Aphids, double rainbow, Cowslips, baby groundhogs, Yellow Lady Slippers, Blueberry blossom, etc., etc.

What a wonderful training these boys and girls are having in observing the countless wonders which Nature has to offer. Our congratulations to Mrs. Anderson and her enthusiastic nature fans. What they will learn in this way they will carry with them for the rest of their lives.

"A Nature Hobby is a shield against the slings and arrows of outrageous fortune; a form of saving for your old age. It is a possession no one can take from you, and one to which you can add indefinitely -- for to understanding there are no limits." 